\title{
DIAGNOSIS KESULITAN MAHASISWA DI UNIVERSITAS KUNINGAN DALAM PEMBUKTIAN MENGGUNAKAN INDUKSI MATEMATIKA BESERTA UPAYA MENGATASINYA MENGGUNAKAN SCAFFOLDING
}

\author{
Azin Taufik \\ (Prodi Pendidikan Matematika) FKIP Universitas Kuningan \\ email : azin.taufik@gmail.com
}

\begin{abstract}
This study was conducted to describe the difficulties of students in the proof using mathematical induction as well as efforts to resolve it using the Scaffolding. Scaffolding is providing assistance given by teachers or peers who are more capable to students so that they can reach their potential level. This study uses a qualitative research design types of case studies, where data is obtained in the form of observations sheet test and an interview with the subject. The subject is based on the results of diagnostic tests that are classified according to type of error is then taken of each group of students as subjects. Based on the research, found the location of the difficulties experienced by students in the proof of proposition using mathematical induction, namely the difficulty in manipulating algebra to show the truth of $\mathrm{P}_{\mathrm{k}+1}$. Of these difficulties, students are given the scaffolding in accordance with the difficulties faced by each student. Depth scaffolding scaffolding provided is a second level that is explaining, reviewing and restructuring and third tiers of scaffolding that is developing conceptual thinking.

The advice given by researchers is the teacher must give emphasis or affirmation special steps to make assumptions and define a form $\mathrm{P}_{\mathrm{k}+1}$, the student must master the other concepts that relate to a given problem, so as to make the connection between $\mathrm{P}_{\mathrm{k}}$ and $\mathrm{P}_{\mathrm{k}+1}$, and similar studies should be conducted with more depth on other types of problems, such as conjecture.
\end{abstract}

Keywords: Diagnosis difficulty, Mathematical Induction, Scaffolding

\section{PENDAHULUAN \\ Latar Belakang}

Pada mata kuliah Teori Bilangan yang dibelajarkan di Universitas Kuningan terdapat submateri mengenai pembuktian dengan induksi matematika. Pentingnya mahasiswa mempelajari induksi matematika ini dinyatakan dalam sebuah kutipan NCTM sebagai berikut: "tujuan ketiga dari kurikulum sekolah adalah untuk meningkatkan perhatian pada pembuktian dengan induksi matematika (NCTM, 1989). Induksi matematika merupakan salah satu prinsip dalam matematika sebagai 
alat berharga untuk membuktikan hasil-hasil yang terkait dengan bilangan bulat, atau hubungan tertentu yang dapat diperluas berlaku untuk semua bilangan asli (Muhstyo, 2009:24).

Induksi matematika secara umum diformalisasikan sebagai berikut: misalkan $\mathrm{P}(\mathrm{n})$ suatu pernyataan untuk masing-masing nilai $n \in$ N. Jika (1) $\mathrm{P}(1)$ pernyataan benar, (2) $\mathrm{P}$ (k) $\rightarrow \mathrm{P}(\mathrm{k}+1)$ untuk setiap bilangan bulat positif $\mathrm{k}$, maka $\mathrm{P}(\mathrm{n})$ benar untuk setiap $n \in N$ (Darmawijoyo, 2010). Davis, dkk (2009) dalam penelitiannya menyatakan bahwa pembuktian dengan menggunakan induksi matematika memiliki tiga langkah, yaitu (1) mengasosiasikan dengan simbol/bahasa dari induksi matematika, (2) proses dari generalisasi langkah pada induksi matematika, (3) validasi (sebagai komponen dari konsep pengembangan).

Berdasarkan hasil wawancara dengan lima mahasiswa Universitas Kuningan yang mengikuti mata kuliah Teori Bilangan diperoleh informasi bahwa dalam membuktikan dengan induksi matematika mereka mengalami kesulitan, hal ini didukung dari pendapat dosen pengampu mata kuliah Teori Bilangan, secara umum mahasiswa mengalami kesulitan dalam langkah kedua yaitu ketika menunjukkan jika $\mathrm{P}(\mathrm{k})$ benar untuk $\mathrm{n}$ $=\mathrm{k}$ maka $\mathrm{P}(\mathrm{k}+1)$ benar untuk $\mathrm{n}=\mathrm{k}+1$ , kesulitan mahasiswa ini sesuai yang dikemukakan oleh Ron dan Dreyfus (2004) dalam mengajarkankan pembuktian dengan induksi matematika secara bermakna pengajar akan menemui kesulitan-kesulitan yang dialami siswa yang mungkin akan dihadapai untuk membuktikan dengan induksi matematika secara baik sebagai pengetahuan matematika yang kompleks.

$\begin{array}{rrr}\text { Kong } & \text { (2003) } & \text { dalam } \\ \text { penelitiannya } & \text { menemukan } & \text { tiga }\end{array}$
kesulitan mahasiswa dalam melakukan pembuktian dengan induksi matematika yaitu kesulitan konseptual, prosedural, dan teknis. Kesulitan konseptual lebih ke pemahaman dari metode pembuktian dengan induksi matematika, hubungan antara hipotesis induksi dan langkah induksi dan kebutuhan dari kasus basis. Kesulitan prosedural lebih kepada kesulitan ketika menemui kasus basis tidak dimulai dengan $\mathrm{n}=1$ dan diberikan pernyataan yang salah. Kesulitan teknis lebih kepada kesulitan dalam memanipulasi aljabar dan ketidaktepatan dalam mensubtitusikan dari variable. Selain tiga jenis kesulitan tersebut Kong juga menemukan bahwa kurangnya pengetahuan mahasiswa terhadap isi dari matematika terhadap topik tertentu sangat mempengarui kemampuan dalam melengkapi pembuktian dengan induksi matematika.

$\begin{array}{rcr}\text { Taufik } & \text { (2014) } & \text { dalam } \\ \text { penelitiannya } & \text { menemukan } & \text { letak }\end{array}$ kesulitan mahasiswa dalam pembuktian menggunakan induksi matematika yaitu: (a) Pada langkah membuat pernyataan, (b) Pada langkah membuat hipotesis, (c) Pada langkah merumuskan bentuk $\mathrm{P}_{\mathrm{k}+1}$, dan (d) Pada 
langkah memanipulasi aljabar untuk menunjukkan kebenaran dari $\mathrm{P}_{\mathrm{k}+1}$. Kong (2003) dalam penelitiannya menemukan fakta bahwa dalam pembuktian menggunakan induksi matematika mahasiswa mengalami kesulitan lebih pada soal pembuktian induksi matematika yang melibatkan konsep turunan/diferensial.

Berdasarkan latar belakang tersebut, penulis berusaha mendiagnosis kesulitan-kesulitan yang dialami oleh mahasiswa di Universitas Kuningan dalam melakukan pembuktian dengan induksi matematika yang difokuskan pada soal pembuktian induksi matematika yang melibatkan konsep turunan/diferensial dan memberikan solusi altenatif untuk permasalahan tersebut. Dengan demikian, kesalahan-kesalahan yang serupa dapat diminimalisir, salah satu bantuan yang dapat diberikan dalam menuntaskan kesulitan mahasiswa dalam pembuktian menggunakan induksi matematika adalah scaffolding.

Scaffolding merupakan proses interaksi antara seseorang yang berkemampuan rendah dengan seseorang yang berpengetahuan lebih dari dirinya. Disini terjadi proses dimana seorang mahasiswa dibantu menuntaskan masalah tertentu melampaui kapasitas perkembangannya melalui bantuan dari seorang dosen atau orang lain yang berkemampuan lebih (Bruner, 1996). Anghileri (2006:39) memberikan tiga tingkatan scaffolding, yaitu:

Environmental provisions, yaitu penataan lingkungan belajar yang memungkinkan berlangsung tanpa intervensi langsung dari guru. (2) Explaining reviewing and restructuring, yaitu melalui penjelasan, peninjauan, dan restrukturisasi, dan (3) developing conceptual thinking, yaitu membangun pemikiran konseptual.

Berdasarkan uraian di atas peneliti mengambil judul penelitian "Diagnosis Kesulitan Mahasiswa dalam Pembuktian Menggunakan Induksi Matematika dan Upaya Mengatasinya Menggunakan Scaffolding".

\section{Tujuan Penelitian}

Tujuan dari penelitian ini sesuai dengan rumusan masalah di atas adalah sebagai berikut.

1. Mendiagnosis kesulitan mahasiswa dalam pembuktian menggunakan induksi matematika.

2. Mendeskripsikan upaya mengatasi kesulitan mahasiswa dalam pembuktian induksi matematika dengan menggunakan scaffolding.

\section{Kajian Teori}

Kesulitan belajar merupakan terjemahan dari istilah bahasa inggris learning disability. Terjemahan yang benar seharusnya adalah ketidakmampuan belajar, akan tetapi istilah kesulitan belajar digunakan karena dirasakan lebih optimistik (Mulyono, 1999). Dalam proses belajar mengajar di sekolah, baik Sekolah Dasar, Sekolah Menengah, maupun Perguruan Tinggi sering kali dijumpai beberapa siswa atau mahasiswa yang mengalami kesulitan dalam belajar. Dengan demikian masalah kesulitan dalam belajar itu sudah merupakan 
problema umum yang khas dalam proses pembelajaran terutama dalam pembelajaran matematika. Aktivitas belajar bagi setiap individu tidak selamanya dapat berlangsung secara wajar. Kadang-kadang lancar, kadangkadang tidak. Kadang-kadang dapat dengan cepat menangkap apa yang dipelajari, kadang-kadang terasa amat sulit. Dalam keadaan anak didik/siswa tidak dapat belajar sebagaimana mestinya, itulah yang disebut kesulitan belajar (Ahmadi dan Widodo, 2004:7).

Secara garis besar faktor-faktor penyebab timbulnya kesulitan belajar terdiri dari faktor internal dan faktor eksternal. Faktor internal tersebut antara lain kelemahan fisik, mental, dan emosional; kebiasaan dan sikapsikap yang salah seperti malas belajar, atau tidak memiliki keterampilan dan pengetahuan dasar yang diperlukan. Sedangkan faktor eksternal antara lain: kurikulum dan pelaksanaan pembelajaran yang tidak tepat, beban belajar yang terlalu berat, terlalu banyak kegiatan di luar jam sekolah, terlalu sering pindah sekolah, dan sebagainya (Mukhtar dan Rusmini, 2003:42-45). Dalam pembelajaran matematika, Brueckner dan Bond dalam (Widdiharto, 2008) mengelompokkan penyebab kesulitan belajar menjadi limafaktor, yakni faktor fisiologis, faktor sosial, faktor emosional, faktor intelektual, dan faktor pedagogis. Faktor intelektual yang menjadi penyebab kesulitan belajar siswa umumnya adalah:

> Siswa kurang berhasil dalam menguasai konsep, prinsip, dan algoritma.
Kesulitan mengabstraksi, menggeneralisasi, berpikir deduktif, dan mengingat konsep-konsep maupun prinsip-prinsip.

Kesulitan dalam memecahkan masalah terapan atau soal cerita.

Kesulitan pada pokok bahasan tertentu saja. Pendapat tersebut sejalan dengan pendapat Sholeh (1998) yang menyatakan bahwa siswa mengalami kesulitan belajar antara lain disebabkan oleh hal-hal sebagai berikut:

Siswa tidak bisa menangkap konsep dengan benar.

Siswa tidak mengerti arti lambanglambang.

Siswa tidak dapat memahami asalusul suatu prinsip.

Siswa tidak lancar menggunakan operasi dan prosedur.

Ketidaklengkapan pengetahuan.

Dalam

pembelajaran matematika, kesulitan siswa dari segi intelektual dapat terlihat dari kesalahan yang dilakukan siswa pada langkahlangkah pemecahan masalah soal matematika yang berbentuk uraian, karena siswa melakukan kegiatan intelektual yang dituangkan pada kertas jawaban soal yang berbentuk uraian tersebut. Beberapa ahli menggolongkan jenis-jenis kesalahan siswa dalam menyelesaiakan soal matematika yakni: kesalahan pemahaman konsep; kesalahan penggunaan operasi hitung; algoritma yang tidak sempurna; dan kesalahan karena mengerjakan serampangan/ceroboh.

Berdasarkan paparan di atas dapat disimpulkan bahwa secara garis besar 
kesulitan yang dialami siswa dapat berupa kurangnya pengetahuan prasyarat, kesulitan memahami materi pembelajaran, maupun kesulitan dalam mengerjakan latihan-latihan dan soalsoal ulangan. Secara khusus, kesulitan yang dijumpai siswa dapat berupa tidak dikuasainya kompetensi dasar tertentu, misalnya siswa tidak menguasai operasi bilangan. Lebih jauh lagi kesulitan yang dialami siswa disebabkan perbedaan setiap individu, baik dalam kemampuan fisik, latar belakang keluarga, kebiasaan, maupun pendekatan belajar yang digunakan.

Avital dan Libeskind menguraikan secara jelas masalah pedagogis dan miskonsepsi yang terjadi ketika mahasiswa belajar induksi matematika. Jenis dari kesulitan mereka yang terlihat adalah (a) konseptual, (b) matematis, dan (c) teknis dimana kesulitan konseptual berarti kesulitaan dalam menghubungkan untuk implikasi dari Pk ke Pk+1 dan kesulitan mendapatkan penggunaan perubahan dari $\mathrm{k}$ menjadi $\mathrm{k}+1$, secara umum kesulitan matematis berarti kesulitan yang berhubungan dengan kasus basis yang tidak sama dengan satu, dan kesulitan teknis adalah kesulitan yang berhubungan ke interpretasi dari penerapan langkah induksi pada suatu kasus khusus dan kesulitan pada manipulasi aljabar dalam pembuktian langkah induksi.

$\begin{array}{rcr}\text { Kong } & \text { (2003) } & \text { dalam } \\ \text { penelitiannya } & \text { menemukan } & \text { tiga }\end{array}$
kesulitan mahasiswa dalam melakukan pembuktian dengan induksi matematika yaitu kesulitan konseptual, procedural dan teknis. Kesulitan konseptual lebih ke pemahaman dari metode pembuktian dengan induksi matematika, hubungan antara hipotesis induksi dan langkah induksi dan kebutuhan dari kasus basis. Kesulitan prosedural lebih kepada kesulitan ketika menemui kasus basis tidak dimulai dengan $\mathrm{n}=1$ dan diberikan pernyataan yang salah. Kesulitan teknis lebih kepada kesulitan dalam memanipulasi aljabar dan ketidaktepatan dalam mensubtitusikan dari variabel. selain tiga jenis kesulitan di atas Kong juga menemukan bahwa kurangnya pengetahuan mahasiswa terhadap isi dari matematika sangat mempengarui kemampuan dalam melengkapi pembuktian dengan induksi matematika.

Dalam penelitian ini jenis kesulitan dalam pembuktian dengan induksi matematika difokuskan pada jenisjenis kesuiltan yang dikemukakan oleh Kong yaitu kesulitan konseptual, kesulitan prosedural, kesulitan teknis, dan kurangnya pengetahuan terhadap isi matematika dan dalam mendiagnosis kesulitan mahasiswa dalam pembuktian menggunakan induksi matematika akan dilihat dari kesulitan-kesulitan dalam langkahlangkah pengerjaan sebagai berikut: (1) Pernyataan yang akan dibuktikan dinyatakan dalam suatu notasi misalkanPn, (2) Pembuktian jelas bahwa hasilnya benar untuk nilai awal yang disubtitusikan, (3) Pernyataan dalam membuat hipotesis induksi jelas dan benar, (4) $\mathrm{Pk}+1$ telah dirumuskan dengan benar, (5) Melakukan manipulasi aljabar untuk menunjukkan 
kebenaran $\mathrm{Pk}+1$, (6) Menarik kesimpulan sebagai tujuan dari pembuktian.

Induksi matematika merupakan salah satu prinsip dalam matematika sebagai suatu alat berharga untuk membuktikan hasil-hasil yang terkait dengan bilangan bulat, atau hubungan tertentu yang dapat diperluas berlaku untuk semua bilangan asli (Muhstyo, 2009:24). Hal inilah yang dimaksud oleh Morash (1991) bahwa bukti dengan induksi matematika merupakan bukti dengan metode khusus yang digunakan pada situasi tertentu, karena bukti dengan induksi matematika hanya dapat digunakan pada sebarang kasus spesial yang dalam pernyataannya meliputi bilangan bulat positif $\mathrm{n}$ atau bilangan asli. Tidak sebarang situasi bisa dibuktikan dengan induksi matematika, namun ada beberapa situasi/kategori khusus pembuktian dengan induksi matematika, kategori-kategori yang dimaksud, sebagaimana dijelaskan oleh Morash (1991) adalah rumus penjumlahan yang biasa dinyatakan sebagai makna notasi jumlah dengan lambang $\sum$, generalisasi dari dua objek ke dalam sebarangbilangan terbatas. Keterbagian dari himpunan induktif yang berlaku semua bilangan bulat lebih dari atau sama dengan $(\leq, \geq)$ untuk suatu bilangan bulat positif n0.

Pengkonstruksian bukti yang terjadi dalam induksi matematika dimulai dari langkah pertama yang menunjukkan bahwa suatu barisan atau pernyataan (misal dilambangkan dengan $\mathrm{S}(\mathrm{n})$ ) benar ketika n dimisalkan dengan salah satu bilangan asli, tergantung pernyataan yang ada dalam soal. Kemudian langkah kedua adalah diklaim benar jika $n=k$ dan langkah terakhir adalah pembuktian bahwa $S(n)$ benar untuk $\mathrm{n}=\mathrm{k}+1$. Pada langkah ketiga inilah dibuktikan proses berpikir yang lebih mendalam guna mencari ide-ide/gagasan untuk kemudian disusun sampai ditemukannya respon mengenai kebenaran $S(n)$ untuk $n=k$ +1 tersebut. Induksi matematika yang akan digunakan dalam buku ini menggunakan tiga jenis induksi, yaitu: (1) induksi baku, (2) induksi kuat, dan (3) induksi perluasan. Kenneth (2005:23) mengemukakan teorema, "A set of positive integers the contain the integer 1, and that has the property that, if it contain the integer $k$, then it also contain $k+1$, must be the set of all positive integers"

Teorema tersebut digunkan pada induksi baku dengan langkahlangkah sebagai berikut:

1. Step 1 (Basis step). Harus ditunjukkan bahwa hasilnya benar untuk $\mathrm{n}=1$.

2. Step 2 (Induction hypotheses). Diasumsikan bahwa hasilnya benar untuk $\mathrm{n}=\mathrm{k}$.

3. Step 3 (Inductive step). Harusditunjukkan bahwa hasilnya benar untukn $=\mathrm{k}+1$.

Teorema untuk induksi kuat diberikan sebagai berikut,

"A set of positive integers that contain the integer 1, and that has the property that, for every positive integer $n$, if it contains all the positive integers 1, 2, $\ldots, n$, then it also contain the integer $n$ +1 , must be the set of all positive 
integers." (kenneth, 2005:25).

Dari teorema tersebut kita peroleh langkah-langkah dalam menyelesaikan dengan induksi kuat sebagai berikut:

1. Step 1 (Basis step). Harus ditunjukkan bahwa hasilnya benar untuk $\mathrm{n}=1$.

2. Step 2 (Induction hypotheses). Diasumsikan bahwa hasilnya benar untuk $\mathrm{n}=2,3, \ldots, \mathrm{k}$.

3. Step 3 (Inductive step). Harus ditunjukkan bahwa hasilnya benar untuk $\mathrm{n}=\mathrm{k}+1$.

Sedangkan teorema untuk induksi perluasan diberikan sebagai berikut, "let $n_{0} \in N$ and let $P(n)$ be a statement for each natural number $n \geq n_{0}$. Suppose that (1) the statement

$P\left(\quad n_{0}\right)$ is true, (2)For all $k \geq$ $n_{0}$ the ruth of $P(k)$ implies the ruth of $P(k+1)$ then $P(n)$ is true for all $n \geq n_{0}$ " (Bartle \& Sherbert, 2000:13).

Dari teorema tersebut kita peroleh langkah-langkah dalam menyelesaikan dengan induksi kuat sebagai berikut:

1. Step 1 (Basis step). Harus ditunjukkan bahwa hasilnya benar untukn $=n_{0}$.

2. Step 2 (Induction hypotheses). Diasumsikan bahwa hasilnya benar untuk $\mathrm{n}=\mathrm{k}>n_{0}$.

3. Step 3 (Inductive step). Harus ditunjukkan bahwa hasilnya benar untuk $\mathrm{n}=\mathrm{k}+1$.
METODE

\section{Metode Penelitian}

Pendekatan yang dipakai dalam penelitian ini adalah pendekatan kualitatif. Karakteristik pendekatan kualitatif, yaitu (1) pengumpulan data secara naratif dan visual, (2) seting latar belakang yang alami, (3) peneliti merupakan bagian dari penelitian, (4) analisis data dilakukan secara induktif, dan (5) peneliti menghindari pengambilan kesimpulan secara dini.

\section{Tempat dan Waktu Penelitian}

Penelitian ini dilaksanakan di Universitas Kuningan pada semester ganjil dan genap tahun ajaran 2014/2015.

\section{Data dan Sumber Data}

Data yang dikumpulkan dalam penelitian ini berupa kata-kata, kalimat-kalimat yang mendeskripsikan kesulitan mahasiswa dalam pembuktian menggunakan induksi matematika.

Adapun uraian data tersebut adalah:

Lembar hasil tes pada studi pendahuluan.

Lembar hasil pekerjaan mahasiswa pada tes diagnosis.

Hasil wawancara subjek penelitian selama pemberian scaffolding.

Hasil rekaman video selama proses pemberian scaffolding.

Lembar hasil pekerjaan mahasiswa pada tes evaluasi.

Sumber data dalam penelitian ini adalah mahasiswa semester empat jurusan pendidikan matematika di 
Universitas Kuningan tahun ajaran 2014/2015 yang terdiri dari 15 mahasiswa, dari 15 mahasiswa ini akan diambil 3 mahasiswa dengan rincian 1 mahasiswa berkemampuan tinggi, 1 mahasiswa berkemampuan sedang, dan 1 mahasiswa berkemampuan rendah.

\section{Prosedur Pengumpulan Data}

Prosedur dalam pengumpulan data dilakukan dengan menggunakan tes dan wawancara.

1. Tes

Ada tiga tes dalam penelitian ini. Tes pertama dilaksanakan saat uji pendahuluan yang diberikan kepada 15 mahasiswa semester empat jurusan pendidikan matematika di Universitas Kuningan pada tanggal 10 April 2015. Tujuan dari pelaksanaan tes ini yang mendukung penelitian adalah untuk mengetahui letak dari kesulitan mahasiswa dalam pembuktian menggunakan induksi matematika secara umum. Tes kedua adalah tes diagnosis yang hanya diberikan kepada 3 mahasiswa yang menjadi subjek penelitian sebelum pemberian scaffolding, dan tes ketiga adalah tes evaluasi yang diberikan kepada 3 mahasiswa yang menjadi subjek penelitian setelah pemberian scaffolding.

2. Wawancara

Wawancara dilakukan dengan bertujuan untuk menggali informasi kesulitan mahasiswa secara mendalam. Dengan wawancara akan memberikan kesempatan kepada mahasiswa untuk melakukan refleksi terhadap apa yang telah dikerjakan.

\section{Instrumen Penelitian}

Instrumen yang digunakan untuk memperoleh data dalam penelitian ini adalah:

1. Peneliti

Peneliti dalam penelitian kualitatif merupakan instrumen utama, hal ini karena peneliti berperan sebagai perencana, pelaksana, serta penyusun laporan.

2. Lembar soal tes

Lembar soal tes yang digunakan dalam penelitian ini adalah tes dengan bentuk essay yang terdiri dari satu soal induksi matematika yaitu soal pembuktian induksi matematika pada konsep turunan/diferensial. Lembar soal ini akan divalidasi oleh ahli, dalam hal ini ahli yang dimaksud adalah ahli pendidikan matematika. Validasi diarahkan pada kesesuaian antara masalah dengan tujuan penelitian. Hasil validasi dari lembar tes menghasilkan skor rata-rata lebih dari 3, sehingga dinyatakan valid. Sedangkan kisi-kisi soal diberikan pada lampiran

\section{Pedoman Wawancara}

Untuk mempermudah pelaksanaan analisis supaya terarah sehingga memperoleh hasil yang diharapkan maka perlu pedoman wawancara. Pedoman wawancara berisi langkah-langkah yang dilakukan peneliti dalam proses menganalisis letak kesalahan mahasiswa.

\section{Rekaman Wawancara dari Video Recorder}


Video Recorder digunakan sebagai salah satu instrumen dikarenakan dengan bantuan rekaman ini diharapkan mampu menambah detail penelitian yang mungkin tidak terekam secara langsung. Selain itu, hasil rekaman ini juga bisa digunakan sebagai pendukung analisis dalam penelitian ini.

\section{Analisis Data}

Analisis data yang digunakan dalam penelitian ini adalah teknik analisis data kualitatif yang meliputi reduksi data (data reduction), penyajian data (data display), serta penarikan kesimpulan dan verifikasi (conclusion drawing and verification).

Proses reduksi data merupakan proses analisis data yang biasa berupa pemilihan, penyederhanaan, penggolongan, pemfokusan, serta transformasi data yang diperoleh. Semua data yang terkumpul dalam penelitian ini baik dari lembar soal tes, wawancara, maupun rekaman video selanjutnya direduksi sehingga dapat diperoleh suatu kesimpulan yang dapat diterima.

Setelah data direduksi dan diperoleh suatu kesimpulan awal, maka proses selanjutnya adalah penyajian data. Penyajian data ini dilakukan dengan menyusun informasi-informasi secara berurutan supaya informasi yang diperoleh dapat digunkan sebagai sumber untuk menentukan suatu kesimpulan. Data yang sudah tersaji selanjutnya akan ditafsirkan serta dievaluasi untuk digunakan dalam proses selanjutnya.
Proses paling akhir dari analisis data kualitatif adalah penarikan kesimpulan. Penarikan kesimpulan dilakukan setelah melakukan analisis data-data yang diperoleh serta menyesuaikan dengan dugaan-dugaan awal yang sudah diverifikasi.

\section{Keabsahan Data}

Untuk menetapkan keabsahan data maka diperlukan pengecekan keabsahan data. Kriteria yang digunakan dalam penelitian ini adalah kriteria derajat kepercayaan (credibility) (Moleong, 2006:324). Derajat kepercayaan dilakukan dengan teknik triangulasi yang disarankan oleh Moleong (2006:327). Triangulasi adalah teknik pemeriksaan keabsahan data yang memanfaatkan sesuatu yang lain. Denzin (dalam Moleong, 2006:330) membedakan empat macam teknik triangulasi, tetapi dalam penelitian ini hanya menggunakan triangulasi sumber. Triangulasi sumber berarti membandingkan dan mengecek balik derajat kepercayaan suatu informasi yang diperoleh melalui waktu dan alat yang berbeda dalam penelitian kualitatif (Patton dalam Moleong, 2006:330). Teknik triangulasi sumber dapat dilakukan dengan cara membandingkan data hasil tes diagnostik dengan data hasil wawancara. 


\section{HASIL DAN PMBAHASAN}

Berikut adalah hasil pekerjaan S1, S1 adalah subjek mahasiswa dengan kemampuan tinggi.

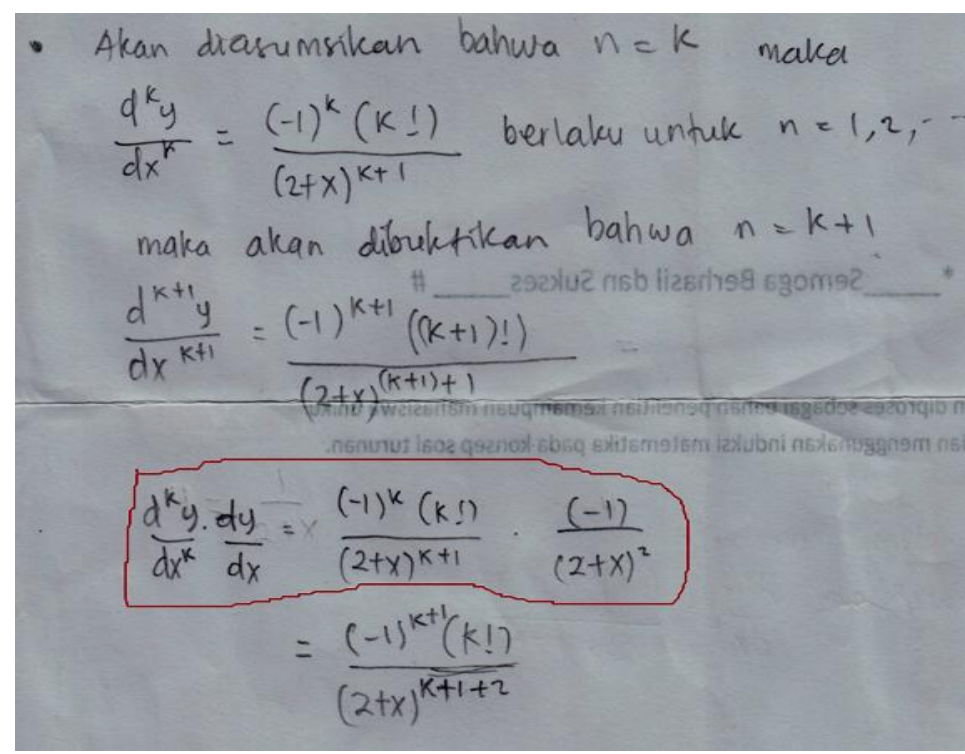

\section{Gambar 1 Hasil Tes Diagnosis S1}

Setelah peneliti menganalisis hasil pekerjaan S1 pada soal di atas, S1 membuat kesalahan dalam langkah melakukan manipulasi aljabar untuk menunjukkan kebenaran $(\mathrm{Pk}+1)$. Pada bagian yang ditandai menunjukkan S1 sudah dapat membuat hubungan $\mathrm{Pk}$ dengan $\mathrm{Pk}+1$. S1 menuliskan $\frac{\mathrm{d}^{\mathrm{k}+1} \mathrm{y}}{\mathrm{dx}^{\mathrm{k}+1}}=\frac{\mathrm{d}^{\mathrm{k}} \mathrm{y}}{\mathrm{dx}^{\mathrm{k}}} \cdot \frac{\mathrm{d}}{\mathrm{dx}}$. akan tetapi dalam proses memanipulasi aljabar, S1 mensubstitusikan nilai $\frac{\mathrm{d}}{\mathrm{dx}}=\frac{-1}{(2+\mathrm{x})^{2}}$ sehingga persamaan yang diminta tidak dapat dibuktikan, dari kesalahan ini menggambarkan bahwa S1 kurang memahami konsep diferensial/turunan.

Untuk membantu S1 dalam pembuktikan peneliti memberikan scaffolding sebagai berikut.

P : Baiklah, pekerjaan nomor 1 pada langkah memanipulasi aljabar ini salah, kamu sudah benar ketika membuat hubungan $\mathrm{Pk}$ dengan $\mathrm{Pk}+1$.
Akan tetapi salah dalam mengartikan symbol $\quad \frac{d^{k+1} y}{d x^{k+1}}=\frac{d^{k} y}{d x^{k}} \cdot \frac{d_{y}}{d_{x}}$. menurut kamu apa arti dari symbol $\frac{\mathrm{d}^{\mathrm{k}} \mathrm{y}}{{\mathrm{dx^{ \textrm {k } }}}^{\mathrm{k}}}$.

S1: $\quad \frac{\mathrm{d}^{\mathrm{k}} \mathrm{y}}{\mathrm{dx}^{\mathrm{k}}} \quad$ melambangkan diferensial ke-k fungsi $y$ terhadap variabel $\mathrm{x}$.

$P \quad$ : Kalau simbol ini artinya apa $\frac{d^{k+1} y}{d^{k+1}}$ ?

S1 : $\quad \frac{\mathrm{d}^{\mathrm{k}+1} \mathrm{y}}{\mathrm{dx}^{\mathrm{k}+1}} \mathrm{~m}$ enyatakan diferensial ke-k+1 fingsi y terhadap variabel $\mathrm{x}$.

$\mathrm{P}$ : Kamu dapat mengetahui arti dari simbol ini dengan baik, menurut kamu bagaimana kamu memperoleh turunan ke-k+1?

S1 : (agak lama) Saya belum tahu Pak.

$\mathrm{P} \quad$ : Baiklah, jika saya mempunyai fungsi $y=2 x^{5}$, kamu tentukan turunan pertama, kedua, ketiga dan keempatnya! 
S1 : Turunan pertamanya $10 \mathrm{x}^{4}$, turunan keduanya $40 \mathrm{x}^{3}$, turunan ketiganya $120 \mathrm{x}^{2}$, dan turunan keempatnya 240x.

$\mathrm{P} \quad$ : Bagaimana kamu memperoleh turunan kedua?

S1 : Dengan menurunkan lagi hasil dari turunan pertamanya Pak.

$\mathrm{P} \quad$ : Bagaimana kamu memperoleh turunan keempatnya?

S1 : Dengan menurunkan lagi hasil dari turunan ketiga Pak.

$\mathrm{P}$ : Sekarang bagaimana cara kamu memperoleh turunan ke-k+1?

S1 : (berpikir sejenak) saya tahu Pak, dengan menurunkan lagi turunan ke-k. $\mathrm{P}$ : Apakah kamu bisa menyelesaikan pekerjaanmu?

S1 : Bisa Pak, saya paham sekarang maksud dari soal nomor 4 ini.

Langkah memanipulasi aljabar untuk menunjukkan kebenaran dari $\mathrm{Pk}+1$, merupakan langkah yang sulit bagi S1, kesulitan pertama muncul karena S1 salah dalam membuat hubungan antara $\mathrm{Pk}$ dengan $\mathrm{Pk}+1$ sehingga dalam proses menguraikan juga mengalami kesalahan, S1 dapat dengan baik menerjemahkan simbol diferensial yang diberikan yaitu $\frac{\mathrm{d}^{\mathrm{k}} \mathrm{y}}{\mathrm{dx}^{\mathrm{k}}}$ dan $\frac{\mathrm{d}^{\mathrm{k}+1} \mathrm{y}}{\mathrm{dx}^{\mathrm{k}+1}}$. Akan tetapi S1 masih salah dalam membuat hubungan antara $\mathrm{Pk}$ dengan $\mathrm{Pk}+1, \quad$ stelah peneliti menyederhanakan soal dengan contoh lain yang lebih sederhana dan memberikan beberapa pertanyaan arahan, $\mathrm{S} 1$ dapat membuat hubungan antara $\mathrm{Pk}$ dengan $\mathrm{Pk}+1$ dengan benar. Berikut adalah lanjutan pekerjaan S1. P : Bapak ulangi lagi pertanyaannya, bagaimana kamu mendapatkan turunan ke-k +1 ?

S1 : dengan menurunkan sekali lagi turunan ke-k Pak?

$\mathrm{P}$ : Simbolkan dengan simbol matematika!

S $1: \frac{d^{k+1} y}{d^{k}+1}=\frac{d}{d x}\left(\frac{d^{k} y}{d x^{k}}\right)$

$\mathrm{P}$ : Ya benar, silahkan kamu lanjutkan pekerjaanmu.

$$
\begin{aligned}
& \mathrm{S} 1: \frac{\mathrm{d}^{\mathrm{k}+1} \mathrm{y}}{\mathrm{dx^{ \textrm {k } + 1 }}}=\frac{\mathrm{d}}{\mathrm{dx}}\left(\frac{\mathrm{d}^{\mathrm{k}} \mathrm{y}}{\mathrm{dx^{k }}}\right) \\
& =\frac{\mathrm{d}}{\mathrm{dx}}\left(\frac{(-1)^{\mathrm{k}}(\mathrm{k} !)}{(1+\mathrm{x})^{\mathrm{k}+1}}\right)= \\
& (-1)^{\mathrm{k}}(\mathrm{k} !)(1+\mathrm{x})^{-(\mathrm{k}+1)} \\
& =(-1)^{\mathrm{k}}(\mathrm{k} !)(-(\mathrm{k}+1))(1+ \\
& \mathrm{x})^{-(\mathrm{k}+1)-1} \\
& =(-1)^{\mathrm{k}}(\mathrm{k} !)(-(\mathrm{k}+ \\
& \text { 1)) }(1+\mathrm{x})^{-(\mathrm{k}+1)-1} \\
& =(-1)^{\mathrm{k}}(\mathrm{k} !)(-1)(\mathrm{k}+ \\
& \text { 1) }(1+x)^{-((k+1)+1)} \\
& =(-1)^{\mathrm{k}}(-1)(\mathrm{k}+ \\
& \text { 1) }(\mathrm{k} !)(1+\mathrm{x})^{-((\mathrm{k}+1)+1)} \\
& =(-1)^{\mathrm{k}+1}(\mathrm{k}+ \\
& \text { 1) }(\mathrm{k} !)(1+\mathrm{x})^{-((\mathrm{k}+1)+1)} \\
& =(-1)^{\mathrm{k}+1}(\mathrm{k}+ \\
& =\frac{(-1)^{\mathrm{k}+1}(\mathrm{k}+1) !}{(1+\mathrm{x})^{((\mathrm{k}+1)+1}}
\end{aligned}
$$

Jadi $\mathrm{Pk}+1$ benar.

$\mathrm{P}$ : Silahkan buat kesimpulan dari pekerjaanmu!

S1 : Karena P1 benar dan $\mathrm{Pk}+1$ benar maka $\mathrm{Pn}$ benar untuk setiap bilangan bulat

positif $n$.

S1 merupakan subjek dengan kemampuan matematika tinggi, S1 bisa membuat hubungan antara $P_{k}$ dengan $P_{k+1}$ yaitu $\frac{\mathrm{d}^{\mathrm{k}+1} \mathrm{y}}{\mathrm{dx}^{\mathrm{k}+1}}=\frac{d}{d x}\left(\frac{\mathrm{d}^{\mathrm{k}} \mathrm{y}}{\mathrm{dx}^{\mathrm{k}}}\right)$, akan tetapi S1 mengalami kesulitan 
dalam memahami symbol deferensial, $\mathrm{P}$ : Silahkan buat kesimpulan dari pekerjaanmu!

S1 : Karena P1 benar dan $\mathrm{Pk}+1$ benar maka $\mathrm{Pn}$ benar untuk setiap bilangan bulat positif $n$.

S1 merupakan subjek dengan kemampuan matematika tinggi, S1 bisa membuat hubungan antara $P_{k}$ dengan $P_{k+1}$ yaitu $\frac{\mathrm{d}^{\mathrm{k}+1} \mathrm{y}}{\mathrm{dx}^{\mathrm{k}+1}}=\frac{d}{d x}\left(\frac{\mathrm{d}^{\mathrm{k}} \mathrm{y}}{\mathrm{dx}^{\mathrm{k}}}\right)$, akan tetapi S1 mengalami kesulitan dalam memahami symbol deferensial, sehingga $\mathrm{S} 1$ mensubstitusikan nilai $\frac{d}{d x}=\frac{-1}{(2+x)^{2}} \quad, \quad$ kesulitan $\mathrm{S} 1$ pada langkah memanipulasi aljabar untuk menunjukkan kebenaran dari $P_{k+1}$ ini termasuk kesulitan karena kurangnya pengetahuan S1 terhadap konsep diferensial dan kesulitan teknis.

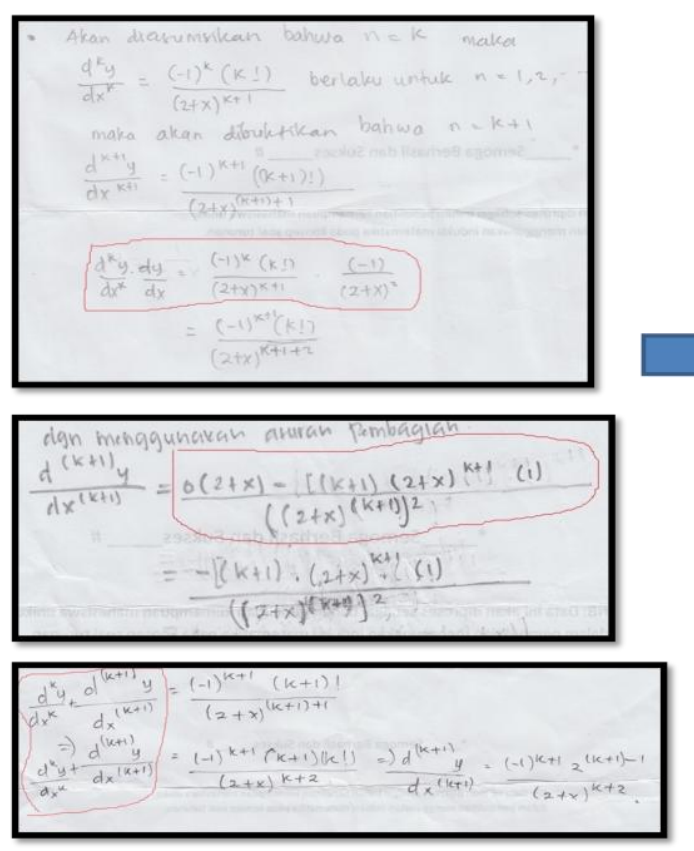

SIMPULAN

Berdasarkan analisis data dan pembahasan maka dapat disimpulkan sebagai berikut:
Dengan mengacu pada scaffolding Anghilery, scaffolding yang diberikan peneliti kepada subjek S1 merupakan scaffolding pada level 2 explaining, reviewing and restructuring dan level 3 developing conceptual thinking yaitu memberikan pertanyaan kepada $\mathrm{S} 1$ arti dari simbol $\frac{\mathrm{d}^{\mathrm{k}} \mathrm{y}}{\mathrm{dx}^{\mathrm{k}}}$ dan $\frac{\mathrm{d}^{\mathrm{k}+1} \mathrm{y}}{\mathrm{dx}^{\mathrm{k}+1}}$ adalah scaffolding reviewing, menyederhanakan masalah dengan memberikan fungsi $y=2 x^{5}$ kemudian menanyakan turunan pertama, kedua, ketiga, keempat sehingga mahasiswa mampu membuat hubungan antara $P_{k}$ dan $P_{k+1}$ adalah scaffolding restructuring dan developing conceptual thinking.

Secara umum hasil dan pembahasan untuk S1, S2 dan S3 diberikan pada bagan berikut ini.
KELOMPOK TINGGI, SEDANG, dan RENDAH

Letak Kesulitan

langkah memanipulasi aljabar untuk

menunjukkan kebenaran dari $P_{k-1}$

Scaffolding

level 2 explaining, reviewing and

restructuring dan level 3 developing

conceptual thinking
Letak kesulitan mahasiswa dalam pembuktian menggunakan induksi matematika yaitu pada langkah memanipulasi aljabar untuk menunjukkan kebenaran mahasiswa 
untuk mengungkapkan dan menulis data-data yang diketahui dari soal, asumsi yang telah dibuat, dan pernyataan yang akan dibuktikan adalah scaffolding reviewing dan restructuring, meminta mahasiswa untuk membuat hubungan antara data yang diketahui dari soal dan asumsi yang telah dibuat, sehingga mahasiswa mampu membuat hubungan antara $P_{k}$ dan $P_{k+1}$ adalah bentuk scaffolding developing conceptual thinking. Sedangkan untuk mahasiswa yang mengalami kesulitan dalam pengoperasian aljabar, scaffolding yang diberikan peneliti merupakan scaffolding pada level 2 explaining, reviewing and restructuring yaitu meminta mahasiswa untuk mencermati kembali hasil pekerjaannya pada baris tertentu sebagai awal dari kesulitan adalah scaffolding reviewing, meminta mahasiswa untuk menjelaskan jawabannya dengan menguraikan dari baris tertentu (bagian yang sulit) dan membandingkan hasilnya dengan baris tertentu (bagian awal dari kesulitan) adalah scaffolding reviewing, peneliti menjelaskan dan mengingatkan mahasiswa mengenai konsep yang dianggap sulit adalah scaffolding explaining.

\section{SARAN}

Dari hasil penelitian ini peneliti memberikan beberapa saran antara lain.

1. Dalam menjelaskan langkahlangkah pembuktian menggunakan induksi matematika, dosen harus memberikan penekanan atau penegasan tersendiri pada langkah membuat asumsi dan merumuskan bentuk $P_{k+1}$, karena dengan memperhatikan kedua langkah ini mahasiswa dapat membuat hubungan antara $P_{k}$ dan $P_{k+1}$ sebagai awal dalam memanipulasi aljabar untuk membuktikan kebenaran dari $P_{k+1}$.

2. Untuk dapat melakukan pembuktian menggunakan induksi matematika dengan benar, mahasiswa harus menguasai konsep-konsep lain yang berhubungan dengan soal yang diberikan, sehingga dapat membuat hubungan antara $P_{k}$ dan $P_{k+1}$.

3. Pada penelitian ini scaffolding yang diberikan adalah upaya pemberian bantuan dari dosen ke mahasiswa, diharapkan untuk penelitian selanjutnya bisa menguraikan dengan mendetail proses scaffolding dari mahasiswa berkemampuan tinggi ke mahasiswa berkemampuan sedang dan mahasiswa yang berkemampuan rendah

\section{DAFTAR RUJUKAN}

Ahmadi dan Widodo. 2004. Psikologi Belajar. Jakarta: PT Rineka Cipta

Anghileri, J. 2006. Scaffolding Practices That Enhance Mathematics Learning, Journal of Mathematics Teacher Education. 9:33-52

Avital, S \& Libeskind, S. (1978). Mathematical induction in the 
classroom: Didactical and mathematical issues. Educational Studies in Mathematics, 9, 429-438.

Bruner, J. (1996). The culture of education. Cambridge, MA: Harvard University Press.

Darmawijoyo. 2010. Argumen Matematika Studi Kasus pada Mata Kuliah Matematika Sekolah II. Jurnal pendidikan matematika volume 4. No.2 Desember 2010.

Davis, dkk.(2009). Learning Proof by Mathematical Induction.Proceedings of the 12 Conference on Research in Undergraduate Mathematics Education (February 26 - March 1, 2009, Raleigh, North Carolina). Published electronically.

Kenneth, H Rosen. 2005. Elementary Number Theory And Its Applications. New York: Greg Tobin.

Kong, Chow Ming. 2003. Mastery of Mathematical Induktion among Junior College Students. The Mathematics Educator 2003, vol. 7 No.2, 37-54.

Moleong, Lexy. 2006. Metodologi Penelitian Kualitatif. Bandung: Remaja Rosdakarya

Morash, Ronald P. 1991. Bridge to Abstrac Mathematics: Mathematical Proof and Structure. New York: McGrawHill, inc.

Muktar dan Rusmini. 2003. Pengajaran Remidial: Teori dan Penerapannya dalam
Pembelajaran. Jakarta: Fifa Mulia Sejahtera.

Muhsetyo, G. 2009. Modul Tori Bilangan.UniversitasNegeri Malang.

Mulyono Abdurrahman. 1999. Pendidikan Bagi Anak

Berkesulitan Belajar. Jakarta: PT Rineka Cipta.

National Council of Teachers of Mathematics (1989).Curriculum and evaluation standards for school mathematics. Reston, VA: Author.

Ron dan Dreyfus. 2004. The Use Of Models In Teaching Proof By Mathematical Induction. Proceedings of the 28th Conference of the International Group for the Psychology of Mathematics Education, 2004 Vol 4 pp 113-120.

Sholeh. 1998. Pokok-Pokok Pengajaran Matematika di Sekolah. Jakarta: Departemen Pendidikan dan Kebudayaan RI.

Taufik, 2014. 2014. Diagnosis Kesulitan Mahasiswa di Universitas Swadaya Gunung Jati dalam Pembuktian Menggunakan Induksi Matematika dan Upaya Mengatasinya Menggunakan Scaffolding. Tesis Tidak Diterbitkan. Malang: PPS UM.

Widdiharto, Rachmadi. 2008.

Diagnosis Kesulitan Belajar Matematika SMP dan Alternatif Proses Remidinya. Paket Fasilitasi Pemberdayaan KKG/MGMP Matematika. Yogyakarta: Depdiknas. 